\title{
On the genus Strandesia Stuhlmann, 1888 (Crustacea, Ostracoda, Cyprididae) with description of Strandesia kimberleyi n. sp. and a key to the extant species of the genus
}

\author{
Ivana Karanovic \\ Western Australian Museum, Locked Bag 49, Welshpool Dc, Wa 6986, Australia
}

Keywords: taxonomy, Ostracoda, Cyprididae, Strandesia, key

\begin{abstract}
Strandesia kimberleyi $\mathrm{n}$. sp. is described from subterranean waters of the Kimberley Region (Western Australia). It belongs to the group of relatively elongated Strandesia Stuhlmann, 1888 species, with no projection on the carapace and with a finely serrated posterior margin of the CR and its claws. The new species is characterized by the asymmetrical valves, elongated terminal segment of the maxillular palp, and the presence of a sensory organ antero-proximally on the first segment of the antennula. This is the first time that this organ is reported in the genus Strandesia. Strandesia purpurascens (Brady, 1886) is redescribed, while for S. variegata (Sars, 1901) and S. obliqua (Brady, 1868) some additional notes on the morphology are provided. A key to identification of 67 species of Strandesia is here given. This number includes a new species and two new combinations $(S$. iheringi (Sars, 1901) comb. nov., and S. mollis (Furtos, 1936) comb. nov.). Strandesia ewaldi is proposed as a nomen novum for S. labiata Roessler, 1990, while 31 species are proposed to be synonyms.
\end{abstract}

\section{Contents}

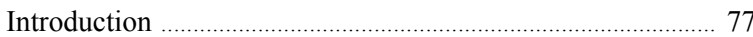

Material and methods ……………………………................. 78

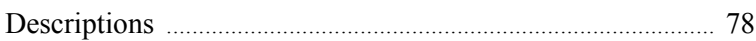

Discussion ............................................................................... 88

List of synonyms proposed in the present paper .................... 90

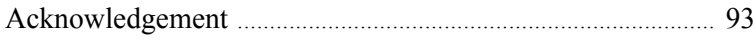

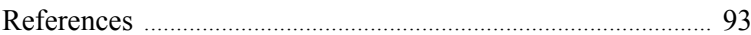

\section{Introduction}

The name Strandesia was first mentioned by Stuhlmann (1888) for ostracods collected in Zanzibar (today Tanzania) and characterized by a big, fin-shaped part on the dorsal side of the right valve. Following Kempf (1980) the genus was introduced as nomen nudum. Vávra (1895) studied the ostracods collected by Stuhlmann and described Strandesia mercatorum Vávra, 1895, which became the type species of the genus Strandesia Stuhlmann, 1888. Since then, some 130 species have been described or subsequently assigned to the genus Strandesia (Kempf, 1980; 1997). Most of them are Recent and freshwater living forms. In the late $19^{\text {th }}$ and early $20^{\text {th }}$ century seven Strandesia-like genera have been described. Claus (1892) introduced Acanthocypris Claus, 1892, with Acanthocypris bicuspis Claus, 1892. Later, Sars (1895) established the genus Cypricercus Sars, 1895 for Cypricercus cuneatus Sars, 1895, while Sars (1901) described Neocypris Sars, 1901 to include six newly described species from South America. All those genera, except Neocypris, have the type species fixed by monotypy. As Sars (1901) did not indicate the type species of Neocypris, Kempf(1980) fixed Neocypris gladiator Sars, 1901 as its type species, following Sars' (1901) publication, where $N$. gladiator was the first one among other Neocypris described in the same paper. It was later shown (Broodbakker, 1983) that $N$. gladiator is a junior synonym of Acanthocypris bicuspis; therefore Neocypris became a junior synonym of Acanthocypris.

McKenzie (1971) established the tribe Cypricercini and included the following genera: Cypricercus Sars, 1895, Tanycypris Triebel, 1959 and Gesa Hartmann, 1957. Although McKenzie (1971) did not mention other genera, on the basis of the diagnostic characters of the tribe, Broodbakker (1983) assumed that McKenzie (op. cit.) included the genera Strandesia and Spirocypris Sharpe, 1903 as well. Eleven years later, McKenzie (1982) described another Strandesia-like genus, Bradleycypris McKenzie, 1982 to encompass several European and North 
American species formerly assigned to Cypricercus. McKenzie (1982) formed a new tribe, Bradleycypridini for the genera Bradleycypris and Spirocypris; Broodbakker (1983) added a monospecific genus, Asterocypris Müller, 1912 to the tribe Cypricercini, and described a new genus, Bradleystrandesia to include all European and North American species of Cypricercus. Bradleystrandesia was actually a replacement name for Bradleycypris, because McKenzie (1982) designated Cypris obliqua Brady, 1883 as the type species, which, according to McKenzie's own diagnosis, could not belong to Bradleycypris, but to the genus Strandesia. Broodbakker (1983) subdivided Strandesia into two subgenera: Acanthocypris and Neocypris. According to the International Code of the Zoological Nomenclature (1999, fourth edition), article 44.1 "when a genus is considered to contain subgenera, the subgenus that contains the type species of the nominal genus is denoted by the same name as the genus, with the same author and name...". Therefore, Broodbakker's division is incorrect from the nomenclatural point of view. In addition, Broodbakker (1983) chose Neocypris obtusata Sars, 1901 for the type species of the subgenus, although Kempf (1980) already did so with the species $N$. gladiator (for further discussion on this point see Martens, 1994). Martens (1994) rejected McKenzie's (1982) tribe Bradleycypridini, but retained the genera Bradleycypris and Bradleystrandesia. The former genus contains Bradleycypris obliqua and possibly some unnamed South American species. Bradleystrandesia contains all European and North American species formerly assigned to Cypricercus. According to all this, the tribe Cypricercini, or the subfamily Cypricercinae, as mentioned by several authors (Hartmann and Puri, 1974; De Deckker, 1981; Martens, 1989, 1994, etc.) comprises the following genera: Acanthocypris, Asterocypris, Bradleycypris, Bradleystrandesia, Cypricercus, Gesa, Spirocypris, Strandesia and Tanycypris. The diagnostic characters and validity of these genera are discussed below and a key to world representatives of Strandesia is given.

The tribe Cypricercini has a worldwide distribution but it is especially diverse in South America, Africa, India and Southeast Asia (see Broodbakker, 1983). In Australia, the tribe is represented with two species only, Strandesia phoenix De Deckker, 1981 and 'Strandesia' dorsoviridis McKenzie, 1965. Strandesia phoenix was described from New South Wales (De Deckker, 1981). 'Strandesia' dorsoviridis has, according to its author, a doubtful generic position, and it is known from Northwestern Australia (McKenzie, 1965). In the present paper I describe a third Strandesia species from Australia, collected from the subterranean waters of the Kimberley Region. Also, I redescribe species Strandesia purpurascens (Brady, 1886), and I give additional notes on the morphology of S. variegata (Sars, 1901) and S. obliqua (Brady, 1868). The first species was collected in India, the second in Africa, the third in Greece.

\section{Material and methods}

Ostracods from Kimberley were collected with haul-nets (mesh size 250 or 350 micrometres) from bores. Haul-nets are actually simple plankton nets of different sizes suitable for the bore, which range from 30 to $180 \mathrm{~mm}$ in diameter. Weighed nets were lowered down into the bore with a bottle screwed on its distal part, then hauled through the water column, usually a number of times. The specimen from India was collected by filtering the groundwater with a plankton net (mesh size 70 micrometers). The net was tied to the inlet delivery that opens into an overhead storage tank, and left there for 2-3 hours until the tank was filled to the brim. Ostracods from Africa and Greece were collected with a modified Cvetkov net (Vigna Taglianti et al., 1969).

For observation under the light microscope, ostracods were dissected in a mixture of distilled water and glycerol (1:1) with fine entomological needles (mark 000). Dissected appendages were mounted in Faure's medium and observed using a Leica DMLS brightfield compound microscope with C-plan achromatic objectives. All drawings were prepared using a drawing tube attached on the microscope.

In the systematic part of this paper, the length of all segments was measured along the midline and length ratios are presented beginning with the proximal segment. The terminology of the appendages follows Martens (1998), while chaetotaxy of all limbs follows the model proposed by Broodbakker and Danielopol (1982), revised for the antenna by Martens (1987). Terminology of the second and third thoracopods follow Meisch (1996), while setae on the antennula are labeled according to Karanovic (2005).

Abbreviations used in text and capture of figures: A1 - antennula; A2 - antenna; CB1, CB2 - setae on the antennular coxobasis; CR - caudal ramus; d1, d2, dp - setae on the basal segment of the second and third thoracopods; En1-6 - endopodal segments of the antennula; Ena, b, c, d - endopodal setae on the antennula; Ex1, 2 - exopodal setae on the antennula; G1, G2, G3, GM, Gm - antennal claws; H - height; L - length; LV - left valve; Md mandible; Mxl - maxillula; RV - right valve; Ta, Ta', Tb, Td setae on the first thoracopod; Te, Tf, Tg, Th1, Th2, Th3 - setae on endopodal segments of the third thoracopod; T1, T2, T3 - first, second and third thoracopods; $\mathrm{t} 1, \mathrm{t} 2$ - medial setae on the second 
endopodal segment of the antenna; W - width; WAM - Western Australian Museum; Y, ya, y1, y2, y3 - aesthetascs; z1, z2, z3 apical setae on the second endopodal segment of the antenna; ZMA - Zoological Museum Amsterdam.

\section{Descriptions}

\section{Strandesia kimberleyi $\mathrm{n}$. sp.}

Figs 1-3

Material. Holotype (female) dissected on one slide and mounted in Faure's medium (ZMA collection), and two paratypes (juvenile female) preserved in $70 \%$ ethanol (WAM C33463), 10-X-2002, collectors: W.F. Humphreys and R. Webb.

Type locality. Bore MB 29D, Argyle Diamond Mine, Kimberley, W.A., Australia, 16² 42 'S 128 $27^{\circ} 17^{\prime \prime}$ E.

Etymology. The species is named after the Kimberley region which is named after the Earl of Kimberley, from where it was collected. It is to be treated as a noun in the genitive singular.

Description of holotype (female). Carapace elongated-ovate in lateral view, asymmetrical, with RV overlapping LV (Fig. 1C). Carapace oblique in posterior view (Fig. 1G). L of carapace equalling $0.908 \mathrm{~mm}$. Valve surface smooth and covered with short setae (Figs. 1C, E). LV overlapping RV ventrally and frontally. Greatest $\mathrm{W}$ around mid-lenght equalling $50 \%$ of $\mathrm{L}$ (Fig. 1E). LV with greatest $\mathrm{H}$ on first third of L, equalling 53\% of L (Fig. 1B, D). Dorsal margin evenly sloping towards the posterior margin, and more steeply so towards the anterior margin. Anterior margin more broadly rounded than the posterior one. Ventral margin concave in the mouth region, slightly more anteriorly with a small lip projection. Calcified inner lamella $23 \%$ of L frontally and $8 \%$ caudally. Inner list well developed and running around the free margins. Zone of concrescence narrow, except around the mouth region where it slightly widens, and with short pore canals. Selvage peripheral. RV (Fig. 1A, F) with greatest $\mathrm{H}$ located at the first third of $\mathrm{L}$, equalling $55 \%$ of L. Dorsal margin more acute on the point of greatest $\mathrm{H}$ than on LV, from where it evenly slopes towards the posterior, more inclined towards the anterior margin. Anterior margin clearly broader than the posterior one. Calcified inner lamella $22 \%$ of $\mathrm{L}$ frontally and $8 \%$ caudally. No inner lists present. Lip process more prominent than on $\mathrm{LV}$, in that region fused zone wide. Flange well developed dorsally. Selvage peripheral.

A1 (Fig. 2G) seven-segmented. CB with two anterior setae (CB1 and CB2), the proximal one transformed into a sensory organ, the distal one normally developed. En1 with a short anterior seta and a welldeveloped Rome's organ. En2 with one seta on each side of the segment, En3, En4 and En5 with four setae each (two posterior and two anterior ones). Posterior setae on En3 and En4 shorter than the anterior ones. Terminal segment with one short posterior seta, two long central setae, and the sensory seta ya, 4.6 times longer than the terminal segment. L ratios of the five distal A1-segments 2.2:1.25:1.25:1.2: 1. L: W ratio of En2 2.2:1.

A2 (Fig. 3D) with swimming setae reaching tips of claws. The sixth seta among the swimming setae only slightly exceeding the distal end of the penultimate segment. Exopod consisting of two short and one long seta. First endopodal segment with only one ventral seta. Second endopodal segment with two setae on the dorsal side and three t-setae on the anterior margin. All three z-setae present and long. Claws G1, G2 and G3 approximately subequal in length, 0.9 times longer than first endopodal seta. Terminal segment short, GM claw 0.7 times as long as the first endopodal segment; Gm 0.5 times the length of the first endopodal segment. All claws finely serrated. Sensory equipment consisting of $\mathrm{Y}$ and $\mathrm{y} 3$ : former one 0.35 times as long as the first endopodal segment, latter one 2.5 times longer than the terminal segment. L ratios of the three endopodal segments 7:4.5:1.

Md palp (Fig. 2A, B) four-segmented. First segment with two plumed S-setae; $\alpha$-seta thin. Second segment with $3+2$ setae in a bunch; $\alpha$-seta densely plumed. Penultimate segment with distal five setae, $\alpha$-seta long, weakly plumed. Terminal segment with one distally plumed claw, two additional claw-like setae, and three short, fine setae.

Mxl palp (Fig. 2E) two-segmented. First segment with five subequally long setae. Terminal segment with two strong claw-like setae (the central one fused with the segment) and four setae. Terminal segment elongated, L:W ratio equals: 1 . Teeth bristles on third endite (Fig. 2D) serrated. 

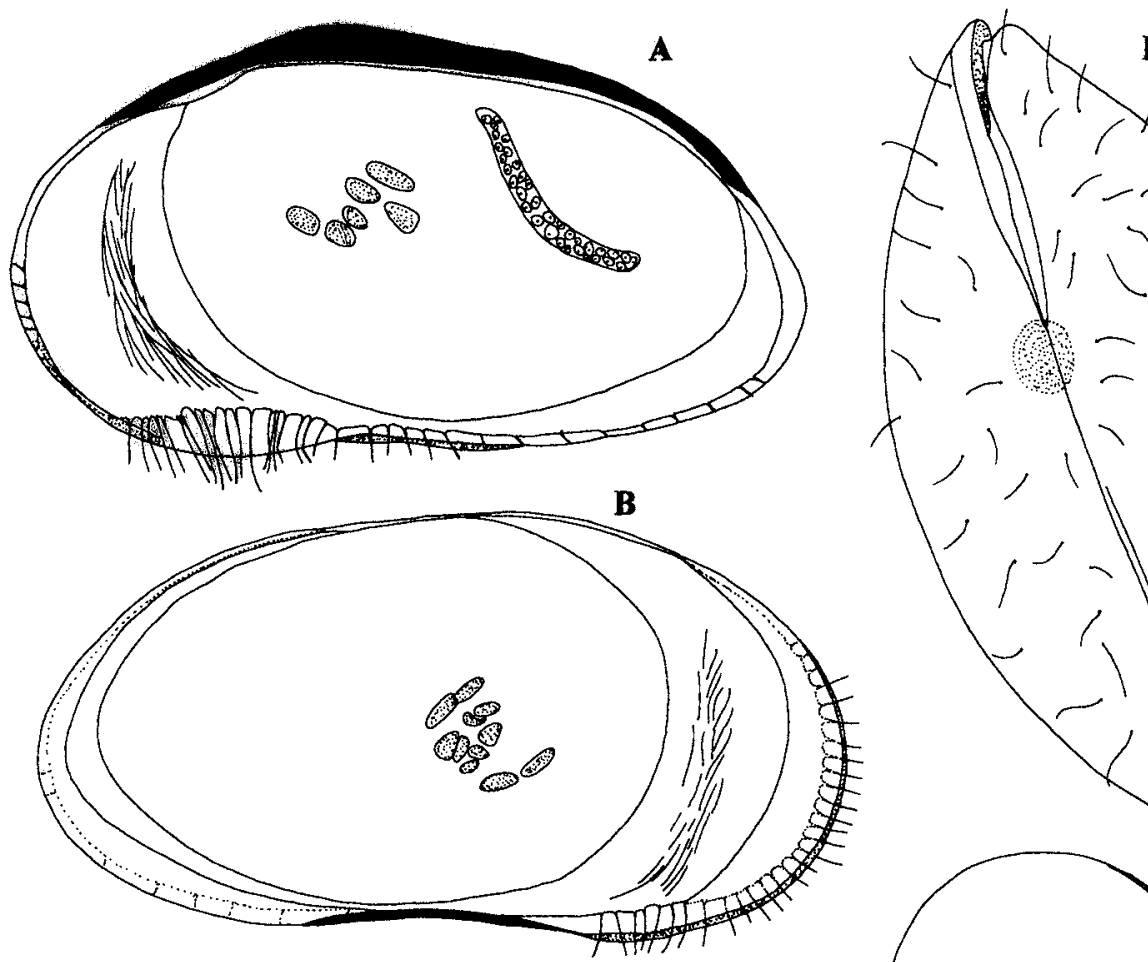

\section{E}
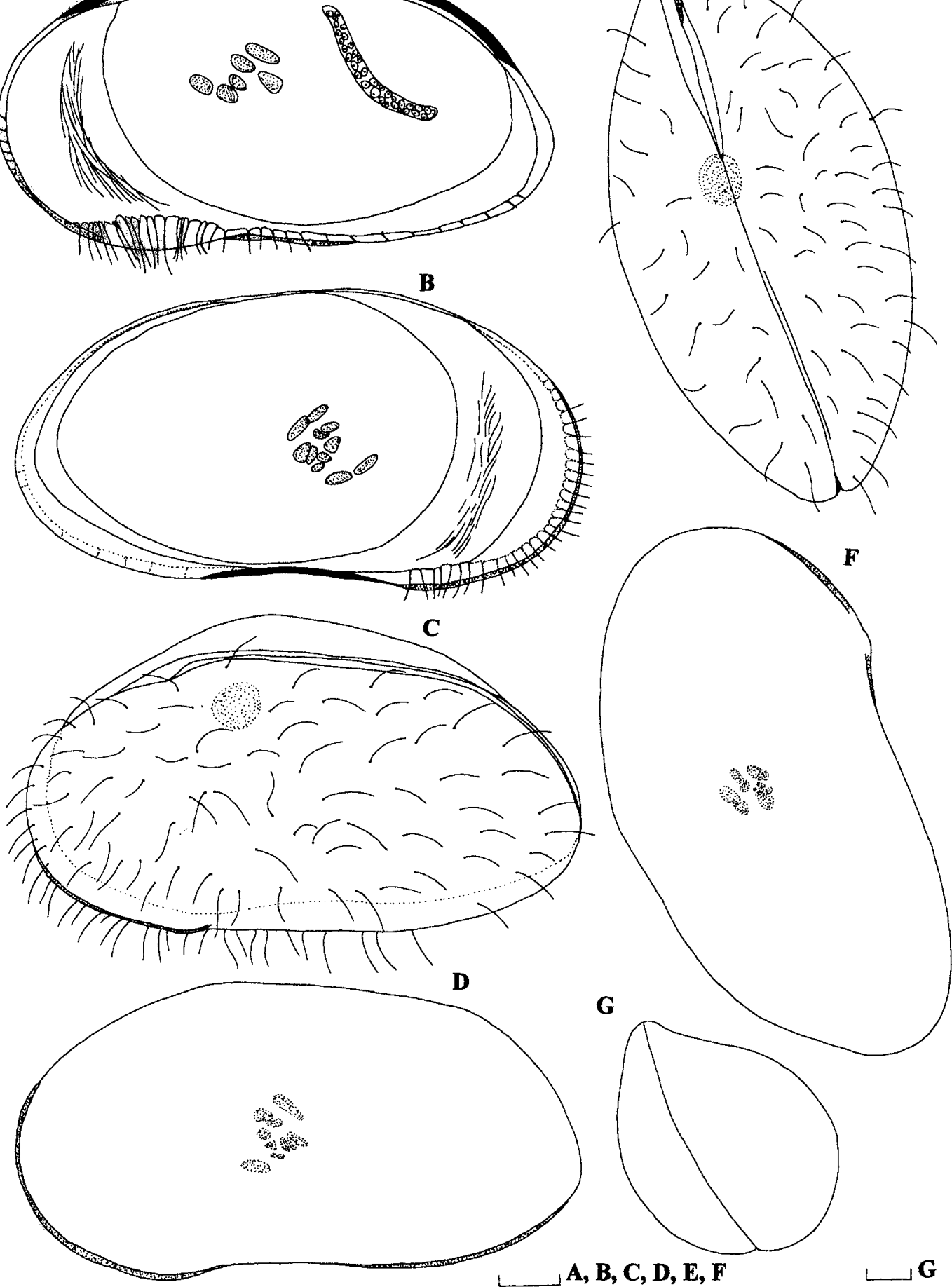

$A, B, C, D, E, F$ G

Fig 1. Strandesia kimberleyi n. sp. Holotype (female): A - RV, internal view; B - LV, internal view; C - carapace, lateral view from left side; D - LV, external view; E - carapace, dorsal view; F - RV, external view; G - carapace, posterior view. Scale $=0.1 \mathrm{~mm}$. 


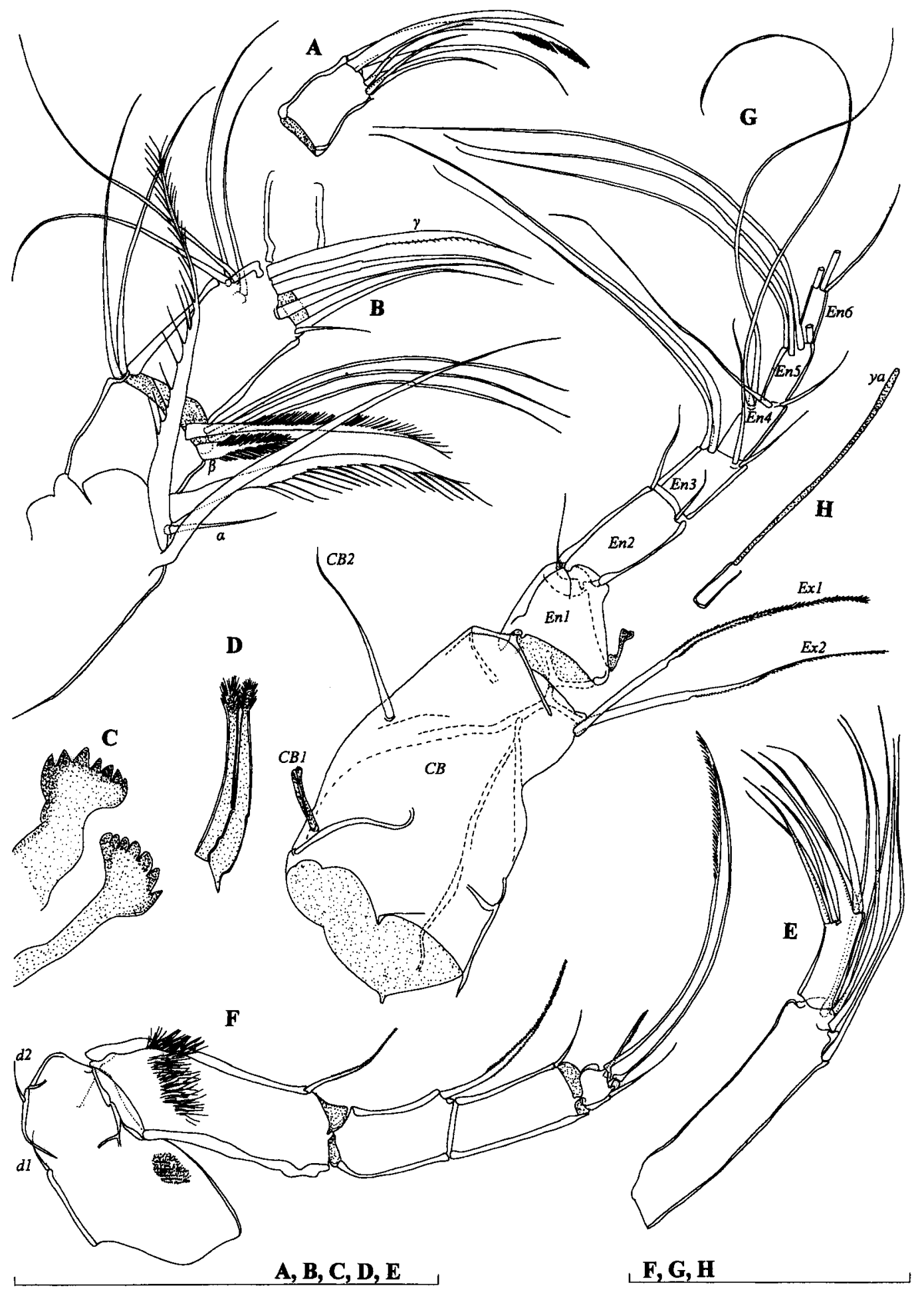

Fig. 2. Strandesia kimberleyi n. sp. Holotype (female): A - terminal segment of Md palp; B - Md palp; C - rake-like organ; D - claws on the third endite on Mxl; E-Mxl palp; F-T2; G-A1; H - terminal segment of A1. Scales $=0.1 \mathrm{~mm}$. 


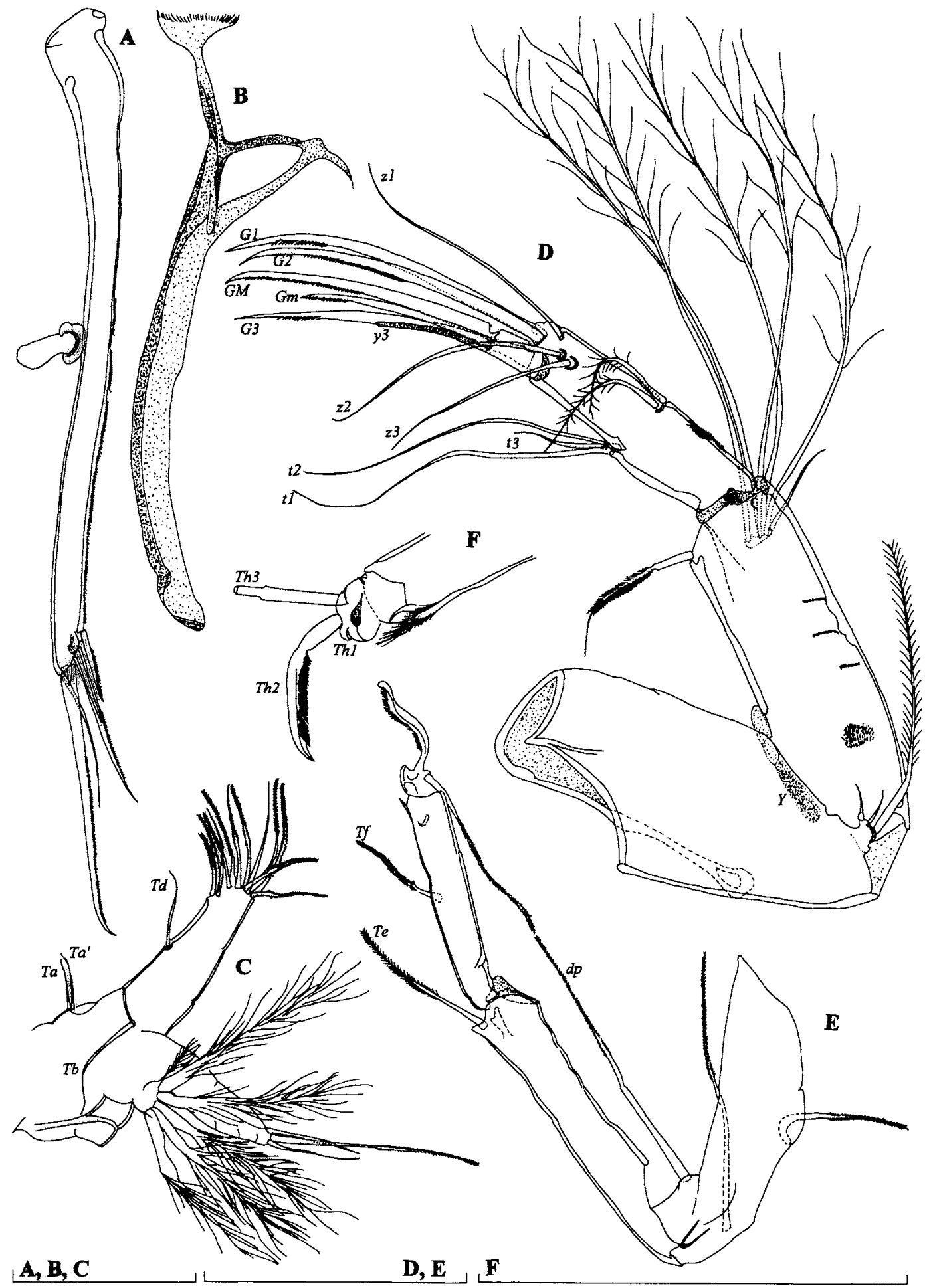

Fig. 3. Strandesia kimberleyi n. sp. Holotype (female): A - Fu; B - furcal attachment; C - T1; D - A2; E - T3; F - T3, detail. Scales = $0.1 \mathrm{~mm}$. 
Rake-like organ (Fig. 2C) with seven strong teeth.

T1 (Fig. 3C), exopod with six setae in the vibratory plate. Two Ta-setae present, $\mathrm{Tb}$ and $\mathrm{Td}$-setae present as well.

T2 (Fig. 2F) five-segmented. Basal segment with both $\mathrm{d} 1$ and $\mathrm{d} 2$ setae short. Seta on the first endopodal segment not reaching the distal end of the following segment. Seta on the second segment well exceeding distal end of the terminal segment. Terminal claw 1.45 times longer than three distal segments combined. Claw distally finely serrated.

T3 (Figs 3E, F) four-segmented. Basal segment with three setae; setae Te and Tf present, Tg seta absent.

CR and attachment (Figs 3A, B). CR long and thin. $\mathrm{L}$ ratios of anterior margin, anterior and posterior claws equalling 4:1.7:1. Anterior seta slightly longer than half $L$ of anterior claw; posterior seta claw-like and slightly shorter than half L of posterior claw. Both terminal claws, and posterior caudal margin finally serrated. Genital field rounded. CR attachment with Triebel-loop situated in main branch, triangular. Dorsal branch very short.

Males not found, female without spermatozoa.

\section{Strandesia purpurascens (Brady, 1886)}

Figs 4 \& 5A

Cypris purpurascen Brady (1886: 298, pl. 28, figs 12-14).

Strandesia purpurascens (Brady, 1886) - Victor and Fernando (1979: 171, figs 83-88); Victor and Fernando (1981: 500, figs 172-177).

Strandesia meghae Harshey and Shrivasov (1987: 44, figs 7: 44, figs 12-20).

Material. One female dissected on a slide, mounted in Faure's medium (ZMA collection) from a freshwater bore-well near Block II on the Acharya Nagarjuna University campus, $13 \mathrm{~km}$ from Gunter town, $16^{\circ} 18^{\prime} \mathrm{N} 80^{\circ} 29^{\prime} \mathrm{E}, 9-\mathrm{XII}-1998$, collector: Y. Ranga Reddy.

Supplementary description of female: Carapace elongated in lateral view (Fig. 4A), symmetrical, RV not surpassing LV. Carapace symmetrical in posterior view. $\mathrm{L}$ of carapace equalling $0.98 \mathrm{~mm}$. Valve surface smooth and covered with short setae. LV overlapping RV on free margins. Greatest $\mathrm{H}$ in the first third of L, equalling $50 \%$ of L. Dorsal margin evenly sloping towards the posterior margin, and inclined towards the anterior margin. Anterior margin more broadly rounded than the posterior one. Ventral margin slightly concave to straight, in the mouth region with a very small lip projection. Calcified inner lamella $15 \%$ of L frontally and $5 \%$ caudally. Inner list not developed. Line of concrescence narrow, pore canals short and straight. Selvage peripheral on LV anteriorly, moved inwards posteriorly. Selvage on RV peripheral.

A1 (Fig. 4B) seven-segmented. CB with one anterior seta (CB2). En1 with one short anterior seta, Rome's organ present. En2 with one seta on each margin of the segment, while En3, En4 and En5 with four setae each (two posterior and two anterior ones). Posterior setae on En3 and En4 shorter than the anterior ones. Terminal segment with one short posterior seta, two long central setae, and sensory seta ya, 1.6 times longer than the terminal segment. L ratios of five distal segments on A1 2.5:1.2:1.2:1:1. L:W ratio of En2 2.6:1.

A2 (Fig. 5A) swimming setae reaching tips of terminal claws. The sixth swimming seta almost reaching the middle of the following segment. Exopod consisting of two short and one long setae. First endopodal segment with only one seta anteriorly. Second endopodal segment with two setae on the anterior margin and four t-setae on the posterior margin. All three z-setae developed. Claws G1, G2 and G3 approximately subequally long and as long as the first endopodal segment. Terminal segment short, GM claw 0.7 times as long as the first endopodal segment; Gm 0.4 times as long as the first endopodal segment. All claws serrated. Sensory equipment consisting of the aesthetascs $\mathrm{Y}$ and $\mathrm{y} 3$ : $\mathrm{Y}$ 0.4 times as long as the first endopodal segment, y3 as long as the terminal segment. L ratios of the three endopodal segments equalling 4.5:4:1.

Md palp 4-segmented. First segment with two plumed S-setae; $\alpha$-seta thin. Second segment with $3+2$ setae in a bunch; $\alpha$-seta densely plumed. Penultimate segment with five distal setae, $\alpha$-seta long and densely plumed. Terminal segment with one distally plumed claw, two additional claw-like setae, and three short, fine setae.

Mxl palp (Fig. 4E) two-segmented. First segment with five subequally long setae, and one short on opposite side. Terminal segment with two stronger setae-claws (central one fused with segment) and four 


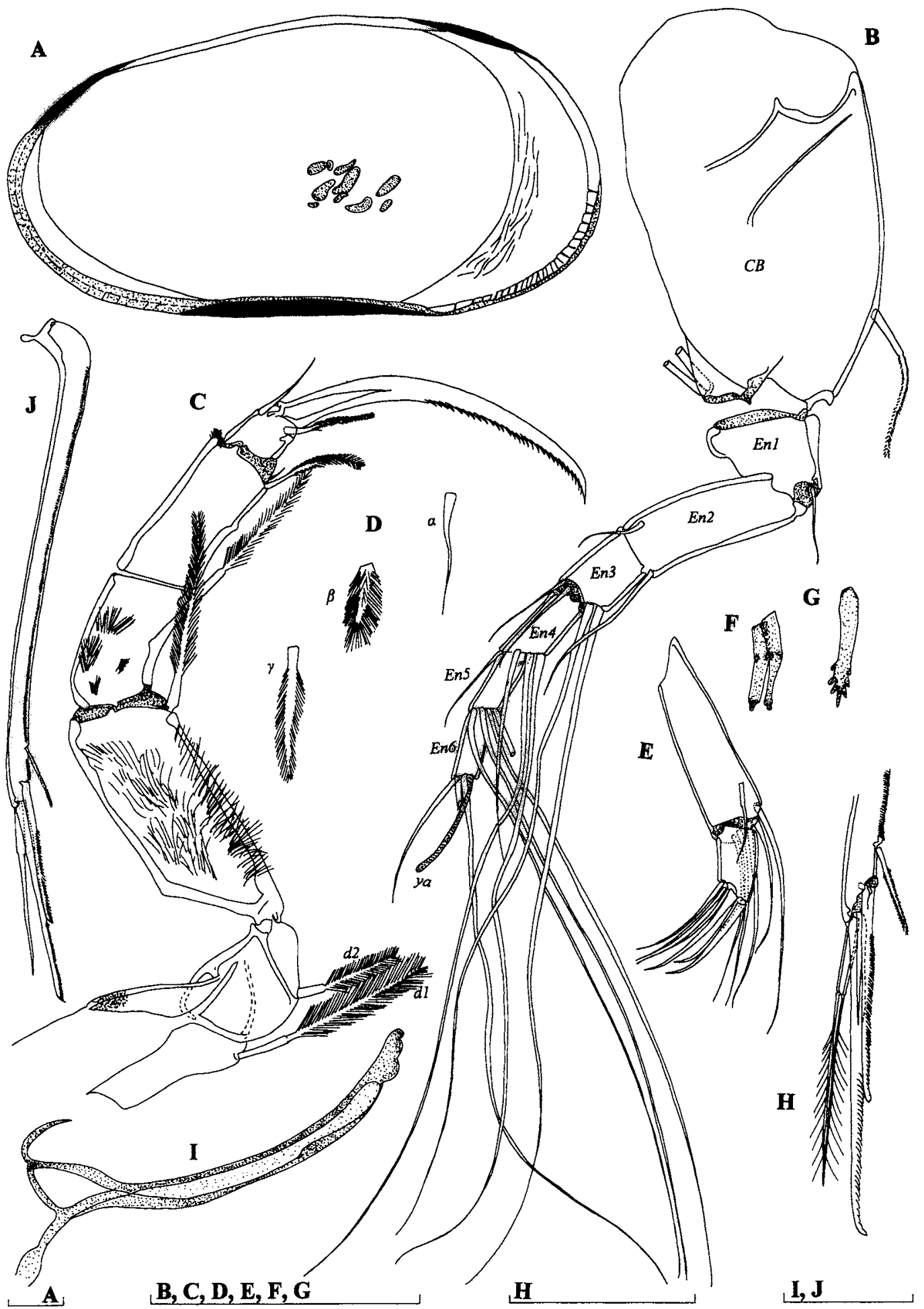

Fig. 4. Strandesia purpurascens (Brady, 1886). Female: A-LV, internal view; B - A1; C - T2; D - Md setae; E- Mxl palp; F, G-claws on third endite of Mxl; H - CR, detail; I - CR attachment; J - CR. Scales $=0.1 \mathrm{~mm}$. 


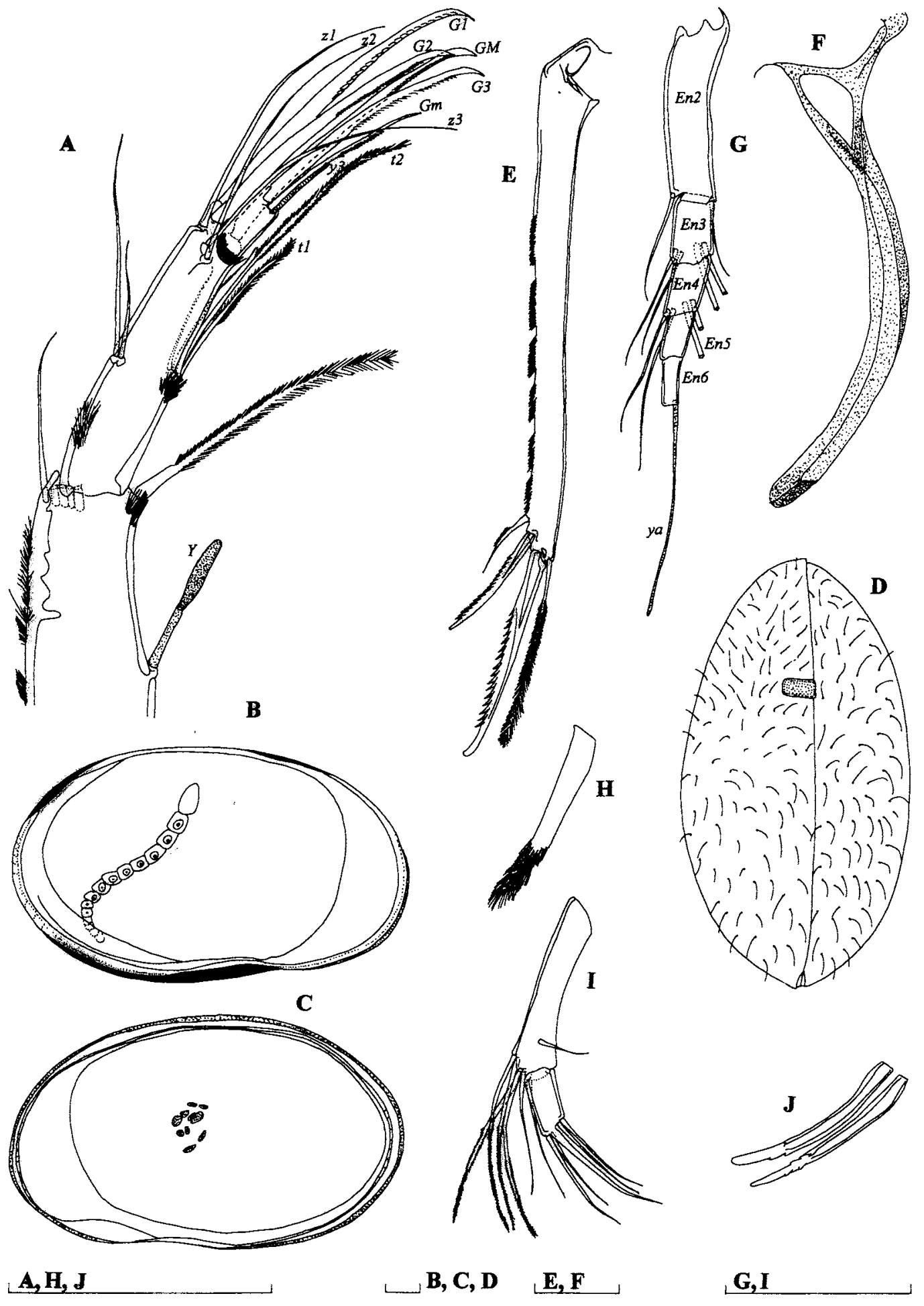

Fig. 5. A Strandesia purpurascens (Brady, 1886). Female; B - J Strandesia variegata (Sars, 1901). Female. A - A2; B - LV, internal view; $\mathrm{C}-\mathrm{RV}$, internal view; D - carapace, dorsal view; E - CR; F - CR attachment; G - A1; H - gamma seta; I - Mxl-palp; J - claws on the third endite of Mxl. Scales $=0.1 \mathrm{~mm}$. 
fine setae. L:W ratio of terminal segment equalling 1.7:1. Claws on third endite toothed (Fig. 4G) or smooth (Fig. 4F).

T1. Exopod with six setae in the vibratory plate. Two Ta-setae, Tb and Td-setae present as well.

T2 (Fig. 4C) five-segmented. Basal segment with both $\mathrm{d} 1$ and $\mathrm{d} 2$ setae long. Seta on first endopodal segment exceeding the distal end of the following segment. Seta on second segment reaching the distal end of the terminal segment. Terminal claw 0.9 times as long as the three distal segments combined. Terminal claw distally strongly serrated.

CR and attachment (Figs 4H, I, J). CR long and thin. $\mathrm{L}$ ratios of anterior margin, anterior and posterior claws equalling 3.2:1.4:1. Anterior seta distinctly claw-like and slightly much longer than half L of the anterior claw; posterior seta claw-like, reaching in length $1 / 3$ of the posterior claw. Both claws finely serrated, also so the posterior margin of the ramus. Genital field rounded. The caudal attachment with Triebel-loop situated in the main branch, triangular.

Males not found, female without spermatozoa.

\section{Strandesia variegata (Sars, 1901)}

Figs 5B-J

Neocypris variegata Sars (1901: 33, pl. 7, figs 14-16).

Strandesia variegata (Sars, 1901) - Broodbakker (1983: 355, figs $13 \mathrm{~F}, \mathrm{~J}, \mathrm{~N}, 14 \mathrm{D})$.

Strandesia ovalis Tressler (1949: 78, figs 14L-O).

Material. One female dissected and mounted on a slide and mounted in Faure's medium (WAM C33464) and 23 female in alcohol (10 - WAM C33465; 13 - ZMA) from River Sangna, Mali, South Africa, 9-XII-1973, collector: L. Boitani.

Supplementary description of female. Carapace subelongated-elliptical in lateral view (Fig. 5B), symmetrical, RV not overlapping LV. Valves symmetrical. L of carapace equalling $1.32 \mathrm{~mm}$. Carapace surface smooth and covered with short setae (Fig. 5D). LV overlapping RV on all free margins. Greatest $\mathrm{W}$ situated around middle, equalling $57 \%$ of $\mathrm{L}$. Greatest $\mathrm{H}$ almost in middle, equalling $58 \%$ of $\mathrm{L}$. Dorsal margin on both valves evenly rounded; anterior and posterior margins broadly rounded and equally wide (Figs 5B, C). Ventral margin slightly convex on LV, while slightly concave on RV. RV with small lip projection in the mouth region. Calcified inner lamella $18 \%$ of $\mathrm{L}$ frontally and $8 \%$ caudally. Inner list developed and running all around margins on LV, while completely absent on RV. Zone of concrescence narrow, except on RV around the mouth region where it widens. Selvage peripheral and on $\mathrm{RV}$ running all around the free margins. On RV two lines of concrescence present.

A1 (Fig. 5G) seven-segmented. CB with one anterior seta. En1 with a short anterior seta and a well-developed Rome's organ. En2 with one seta on each margin of segment; En3, En4 and En5 with four setae each (two posterior and two anterior one). Posterior setae on En3 and En4 shorter than anterior ones. Terminal segment with one short posterior seta, two long central setae, and sensory seta ya, 4.2 times longer than terminal segment. L ratios of five distal segments on A1 4:1.5:1.2:1:1. L:W ratio of En2 4:1.

A2 with swimming setae reaching tips of claws. The sixth seta well exceeding the penultimate segment. Exopod consists of two short and one long seta. First endopodal segment with only one posterior seta. Second endopodal segment with two anterior setae and three t-setae on the posterior side. All three zsetae present and long. Claws G1, G2 and G3 subequally long and as long as the first endopodal segment. GM claw 0.8 times as long as the same segment; Gm 0.6 times longer than the first endopodal segment. All claws serrated. Sensory equipment consists of aesthetascs $\mathrm{Y}$ and $\mathrm{y} 3$ : former one 0.3 times as long as the first endopodal segment, later one 2 times longer than the terminal segment. L ratios of the three endopodal segments equalling 5.3:4.4:1.

Md palp four-segmented. First segment with two plumed, S-setae; $\alpha$-seta thin. Second segment with $3+2$ setae in bunch; $\alpha$-seta densely plumed. Penultimate segment with five setae, $\alpha$-seta densely plumed.

Mxl palp (Fig. 5I) two-segmented. First segment with six subequally long setae, and one shorter on opposite side. Terminal segment with two stronger claw-like setae (central one fused with the segment) and four fine setae. Terminal segment not elongated, $\mathrm{L}$ : W ratio equals 2:1. Claws on third endite (Fig. 5J) finely toothed.

Rake-like organ with seven strong teeth.

$\mathrm{T} 1$ exopod with six setae in vibratory plate. Two 

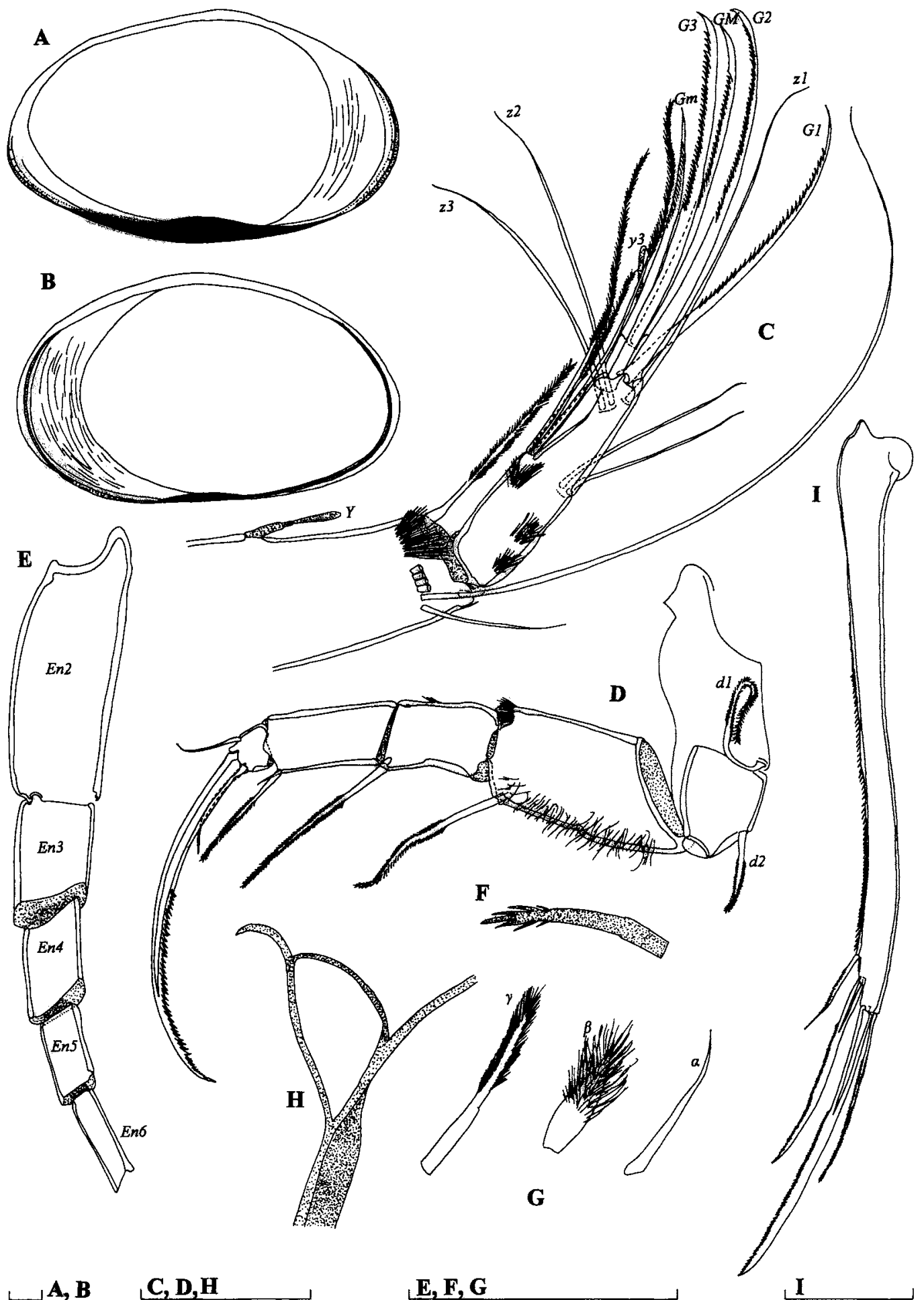

$ـ \mathbf{A}, \mathbf{B} \quad$ C, $, \mathbf{D}, \mathbf{H}$
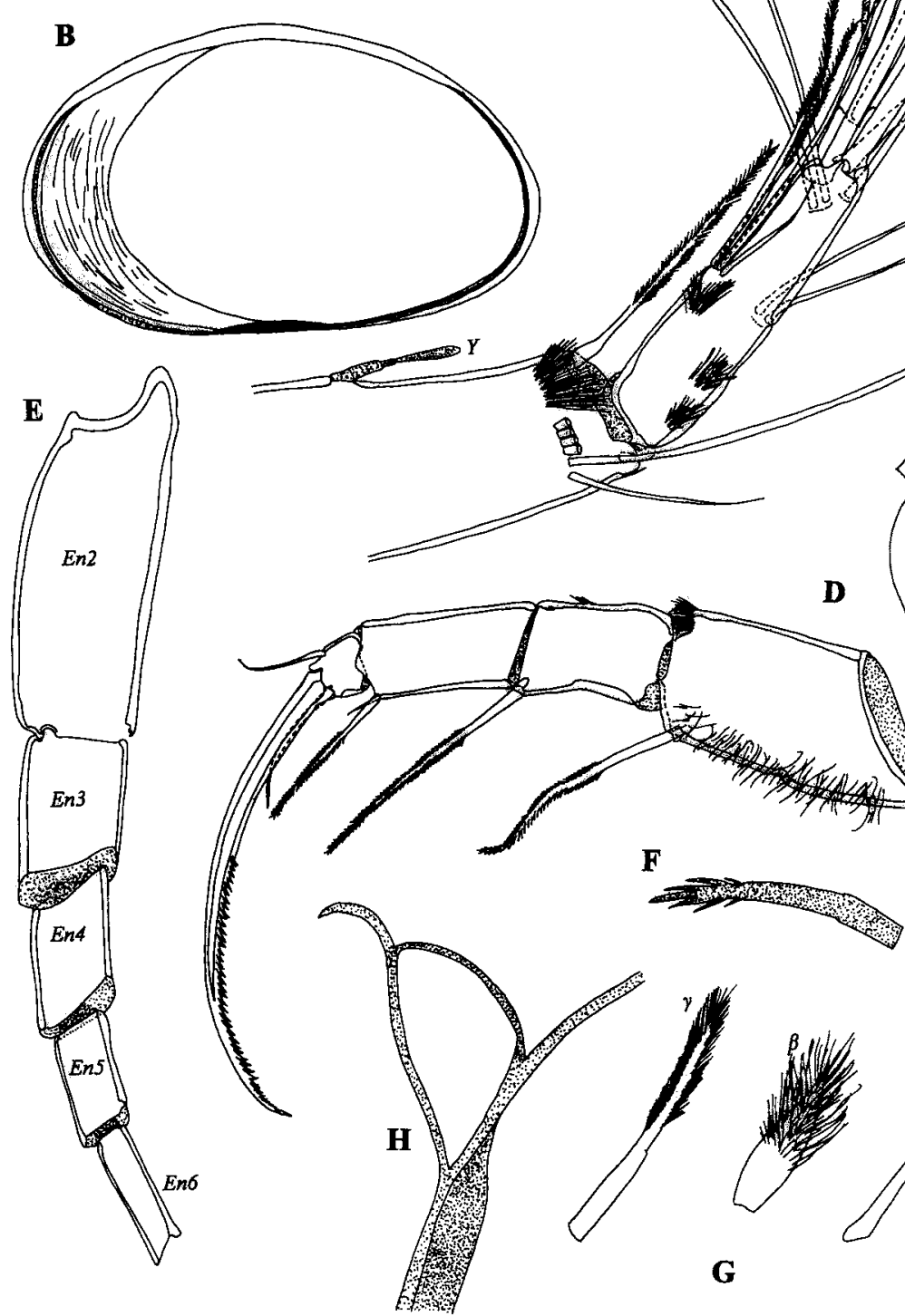

स.s.

$\mathbf{E}, \mathbf{F}, \mathbf{G}$

I

Fig. 6. Strandesia obliqua (Brady, 1868). Female. A - LV, internal view; B - RV, internal view; C - A2; D - T2; E - five terminal segments of A1; F - claws on the third endite of Mxl; G - Md setae; H - Triebel's loop; I - CR. Scales = $0.1 \mathrm{~mm}$. 
Ta-setae present, Tb and Td-setae present as well.

T2 five-segmented. Basal segment with long d1 and $\mathrm{d} 2$ setae. Seta on first endopodal segment almost reaching distal end of the penultimate segment. Seta on the second segment exceeds distal end of terminal segment. Terminal claw 1.2 times longer than the three distal segments combined. Claw serrated distally.

CR and attachment (Figs 5E, F). Furcal ramus long and thin. $\mathrm{L}$ ratios of anterior margin, anterior and posterior claws equalling 3.7:1.7:1. Anterior seta almost reaching tip of the anterior claw; posterior seta slightly shorter than half $\mathrm{L}$ of the posterior claw. Both claws strongly serrated, as well as the posterior margin of the CR. Genital field rounded. Caudal attachment with Triebel-loop situated in the main branch, triangular. Dorsal branch short.

Males not found, female without spermatozoa.

\section{Strandesia obliqua (Brady, 1868)}

Fig. 6

Cypris obliqua Brady (1868: 364, pl. 23, figs 33-38).

Cypricercus obliquus (Brady, 1868) - Sars (1925: 121, pl. 55, Fig. 3).

Bradleycypris obliquus (Brady, 1868) - McKenzie (1982: 411).

Strandesia (Neocypris) obliqua (Brady, 1868) - Broodbakker (1983: 358, Figs 14E, G, K).

Strandesia obliqua (Brady, 1868) - Fox (1967: 776).

Bradleycypris obliqua (Brady, 1868) - Meisch (2000: 312, figs 131, 132).

Strandesia vavrai (G.W. Müller, 1898) - Bronstein (1947: 130, fig. 57, Tab. 5, figs 7, 9).

Strandesia clorocelis Anichini (1967: 8, fig. 2).

Strandesia mulargie Anichini (1967: 12, fig. 3).

Cypricercus alacer Meisch (1979: 191, figs 1-11).

Strandesia sphaeroidea Broodbakker (1983: 342, figs 7 A-C, 8).

Material. One female dissected on one slide and mounted in Faure's medium (WAM C33466) from freshwater well in industrial area of Patras, main road Patras-Pigros, northern Peloponnesus, Greece, $38^{\circ} 13^{\prime} \mathrm{N} 23^{\circ} 43^{\prime} \mathrm{E}, 4-\mathrm{IV}-1978$, collector: G.L. Pesce.

Short description of female. Carapace subelongatedovate in lateral view (Figs 6A, B), symmetrical, RV not overlapping LV. Carapace oblique in frontal posterior views. $\mathrm{L}$ of carapace equalling $1.29 \mathrm{~mm}$. Shell surface smooth and covered with short setae. LV overlapping RV frontally, and ventrally. Greatest $\mathrm{H}$ almost on first third of L, equalling $59 \%$ of $\mathrm{L}$. Dorsal margin on both valves sloping evenly to- wards posterior and more inclined towards anterior margin; anterior margin wider than posterior one. Ventral margin slightly convex on LV, while straight on RV. Calcified inner lamella $17 \%$ of L frontally and $8 \%$ caudally. Inner list developed and running almost all around margins on LV, while completely absent on RV. Line of concrescence narrow. Selvage peripheral on LV, while moved inwards on RV.

A1 (Fig. 6E) with $L$ ratios of five distal segments 2.55:1.25:1:1:1.1. L:W ratio of En2 2.2:1.

A2 (Fig. 6C) with swimming setae reaching tips of claws. The sixth seta reaching $1 / 3$ of penultimate segment.

Claws on third endite on Mxl (Fig. 6F) strongly toothed.

Md palp four-segmented, $\alpha$-seta thin, $\alpha$-seta densely plumed, $\alpha$-seta long and plumed.

CR and attachment (Fig. 6I, H). CR long and thin. L ratios of anterior margin, anterior and posterior claws equalling 2.7:1.4:1. Anterior seta exceeding half length of the anterior claw; posterior seta short. Both claws finely serrated, as well as posterior caudal margin. Genital field rounded. Attachment of the CR with Triebel-loop situated in main branch, triangular.

Males not found, female without spermatozoa.

\section{Discussion}

Strandesia kimberleyi $\mathrm{n}$. sp. belongs to the group of species relatively elongated, without any valve projections or tubercules along the valve margins, and with a smooth or finely serrated posterior margin of the CR and claws. These species are:

1. S. calapanensis Tressler, 1937, described from Philippines (Tressler, 1937; Victor and Fernando, 1981);

2. S. complexa Victor and Fernando, 1982 from the Philippines (Victor and Fernando, 1981);

3. S. kraepelini (Daday, 1910) from Malaysia and Indonesia (Victor and Fernando, 1981);

4. S. purpurascens (Brady, 1886), described from Ceylon and also found in India (Victor and Fernando, 1979a);

5. S. saetosa Hartmann, 1964, described from India (Hartmann, 1964; Victor and Fernando, 1979a);

6. S. sexpunctata Klie, 1932, described from Java (Klie, 1932), later reported from the Philippines (Victor and Fernando, 1981). 
The new species has extremely asymmetrical valves in the lateral view, it has a sensory organ on the first segment of the A1 (CB1 seta on Fig. 2G), an elongated terminal segment on the Mxl palp; a very short d1 seta on the T2 as well as the seta on the first endopodal segment of the same appendage. Neither of these features is present in the above six species. Actually, sensory organ on the first A1 segment (CB1 seta) has so far not been reported in the genus Strandesia. This organ has been described by Wouters (1999) in the subfamily Paracypridinae, and defined as a transformed most proximal seta by Maddocks (2000). In addition, it seems that no species of the genus Strandesia has the seta CB1 present at all.

There is a great difference in the $\mathrm{L}: \mathrm{W}$ ratio of the terminal segment of the Mxl palp among the Strandesia species. Several species described from the West Indies, S. longula Broodbakker, 1983, S. cavernicola Broodbakker, 1983 and S. venezolana Broodbakker, 1983 (see Broodbakker, 1983) have an elongated terminal segment of the palp. These species, like the new species, do not posses a mediodistal seta on the penultimate segment on the same appendage. All three species of the West Indies have elongated carapace but their CR are heavily serrated. It seems that the species of the genus Tanycypris Triebel, 1959 also have elongated Mxl-palp segments (see Broodbakker, 1984), but with a medio-distal seta. In many Strandesia species the segment in question is not described or is only schematically drawn. On the other hand, much attention has been paid to the appearance of the teeth bristles on the third endite of the Mxl. The presence of teeth, spines or setae on these bristles is variable within a given species, or even in one specimen (see $S$. purpurascens in this paper). It is also dependent on the position of the appendage under the cover-slip. Comparing with the other Australian species, Strandesia kimberleyi differs above all in the shape of the carapace. In $S$. phoenix De Deckker, 1981, the carapace is globular. This species is synonymized here with $S$. rouxi Méhes, 1939, described from New Caledonia (Méhes, 1939), because of the identical appearance of the carapace and soft parts. The other species from Australia, which was tentatively assigned to the genus Strandesia - 'S.' dorsoviridis McKenzie, 1965 is not taken into account because of the shape of the terminal segment of the Mxl-palp (rectangular) and very distal position of the posterior seta of the CR (Mc-
Kenzie, 1965), a character which is unknown in the other species of the genus.

The only difference between the specimen of Strandesia purpurascens, redescribed in the present paper, and the population of the same species from India (Victor and Fernando, 1979a) and the Philippines and Malaysia (Victor and Fernando, 1981) is the shape of the anterior seta of the CR. This seta is longer and thinner in the other Indian, Malay and Philippine populations than in the specimen presented here. They also have a more roughly serrated posterior margin of the CR. I have chosen not to describe a new species, because I had only one specimen and the characters of the CR are likely to be variable. Another species described from India, $S$. meghnae Harshey and Shrivastav, 1987 is synonymized with $S$. purpurascens because of the identical appearance of the carapace. Although the soft parts are poorly described, the furca of $S$. meghnae is identical with the specimen described herein (see Harshey and Shrivastav, 1987).

The second species redescribed here is $S$. variegata Sars, 1901, collected from Mali. This species was first described from Brazil (Sars, 1901). Although geographically very distinct, the population from Mali has an identical carapace shape, long second endopodal segment of A1, and identical CR as in the South American population (see Broodbakker, 1983). An African species, S. chondropherusa Rome, 1965 described from l'Upema National Park in Africa (Rome, 1965), has a carapace like $S$. variegata from Mali, but the furca is finely serrated. Strandesia chondropherusa is only tentatively placed as a synonym of $S$. wolterecki Tressler,1937; while $S$. ovalis Tressler, 1950 is synonymized with $S$. variegata. The only difference between all these species is seen in the serration of $\mathrm{CR}$. If this proves to be a variable feature, then they are all junior synonyms of $S$. variegata.

The last species, additionally described in the present paper, is S. obliqua (Brady, 1868). It is the only widely distributed species of the genus. At least the following four species are hardly, or not at all different from S. obliqua: S. clorocelis Anichini, 1967; S. sphaeroidea Broodbakker, 1983; S. mulargie Anichini, 1967; S. vavrai (Müller, 1898). It is possible that some more species with ovoid-elliptical valve form are only variations of $S$. obliqua.

The key presented in this paper includes as many 
species as possible, but the following species do not have enough characters to be identified as separate ones nor to be synonymized with others: Strandesia cyprinotoides Klie, 1938; S. diversicolor Klie, 1938; S. itapeva Tressler, 1950; S. marmorata (Brady, 1868); S. riograndensis Tressler, 1950; S. strandesoides (Müller, 1898); S. tietensis Tressler, 1949; S. taeniata (Vávra, 1895); S. towoetensis 1937; and S. unguiculata Brehm, 1938. A new name - Strandesia ewaldi nom. nov. is proposed for the species $S$. labiata Roessler, 1990, because it is a homonym with S. labiata Hartmann, 1964. Two species, S. iheringi (Sars, 1901) comb. nov. and S. mollis (Furtos, 1936) comb. nov. are new combinations. The first species was originally described in the genus Cypris O.F. Müller, 1776, the second one in the genus Cypricercus Sars, 1895. The reason is an obvious morphological affinity of these two species with Strandesia. Some of the synonyms proposed herein may not be correct. This will probably be clear after checking of the type material. However, the available descriptions of these species, usually combined with the geographical distribution formed my opinion. The majority of the Strandesia species is insufficiently described. In a purpose of retaining as many names as possible, I have included many species distinguishable only after the patterns on their carapace, which could easily be changed with the mode of preservation. The key includes all the South African species of the genus Cypricercus Sars, 1895. Even Müller (1912) placed these species in Strandesia. At present stage, Cypricercus cannot be distinguished from Strandesia. It may define a group of species where RV terminates very narrowly or even with an extension. These species can be found in South America and Africa. However, their soft part morphology is so similar and overlapping with Strandesia that the validity of the genus Cypricercus is in question. If it is only a synonym of Strandesia, than the name of the tribe, Cypricercini should be changed to Strandesini. Species assigned to the genus Bradleystrandesia Broodbakker, 1983 are not included in the key. Their main and, for now, the only diagnostic character is the position of the Triebel-loop, which is set in the dorsal, not main branch of the furcal attachment. However, this seems also to be variable between species (see Martens, 1989). The genus Bradleycypris McKenzie, 1982 is disregarded, as its only species, $S$. obliqua is a typical example of the genus Strandesia. Meisch (2000) pointed another character of the genus Bradleycypris, the heavily build shaft of the CR. However, the majority of the Strandesia species have the same appearance of the attachment. Anyway, it was stressed by Broodbakker (1983) that Bradleystrandesia is a replacement name for Bradleycypris. The genera Tanycypris Triebel, 1959 and Astenocypris Müller, 1912 appear to be the only well-defined genera of the tribe. The first one is characterized by a very elongated carapace and wide anterior inner calcified lamella, the later one has many distinguishing characters on the valves and soft parts. The position of Spirocypris Sharpe, 1903 in the tribe is not certain as, according to McKenzie (1982), Sharpe did not describe the appearance of the attachment of CR. Gesa Hartmann, 1957 was described on immature females, and it can be a senior synonym of Tanycypris (see Martens, 1989). The genus Acanthocypris Claus, 1892 has many overlapping characters with Strandesia and all species assigned to it by Broodbakker (1983) are here placed in the genus Strandesia. However, this genus may be defined with a group of the South American species with more or less elongated carapace, dorsal extension on the RV, tubercles on the margin and heavily serrated CR.

An uncertainly regarding the generic diagnosis leaves Strandesia a 'bulky' genus with many forms and probably many phyletic lineages. The species of Strandesia differ only in the characters of the carapace, while soft parts are extremely conservative. A further point in the investigation of this large genus should be the structure of the Mxl, the $\gamma$-seta of the Md-palp and the position of the flanges and selvages on the valves. There is no doubt that the genus Strandesia and the other 'Cypricercine' genera need an urgent revision (Martens, 1989; George and Martens, 1993).

\section{List of synonyms proposed in the present paper}

Reference sources are indicated between square brackets. All previously established synonyms are not listed. Both Strandesia odiosa (Moniez, 1892) and S. flavescens Klie, 1932 are considered valid species. This is in opposition to Victor and Fernando (1979b, 1981) who suggested the latter species to be a junior synonym of the former one. However, S. odiosa does not posses tubercles along the valve margins, while tubercles are present in the other species. 
Strandesia bicuspis (Claus, 1892) [Claus, 1892; Broodbakker, 1983]

=S. denticulata Tresseler, 1949 [Tressler, 1949]

Strandesia bornemiszai Klie, 1935 [Klie, 1935; Broodbakker, 1983]

= S. postica Rome, 1962 [Rome, 1962]

= S. prava Klie, 1935 [Klie, 1935]

Strandesia calapanensis Tressler, 1937 [Tressler, 1937; Victor and Fernando, 1981]

?= S. indica Hartmann, 1964 [Hartmann, 1964; Victor and Fernando, 1979a]

$=S$. dorsolonga Rome, 1962 [Rome, 1962]

= S. elongata Hartmann, 1964 [Hartmann, 1964; Victor and Fernando, 1979a]

Strandesia centrura Klie, 1940 [Klie, 1940]

$=S$. ariariensis Roessler, 1986 [Roessler, 1986]

$=S$. variabilis Roessler, 1986 [Roessler, 1986]

Strandesia cuneatus (Sars, 1895) [Sars, 1895; Sars, 1924]

$=S$. caudata Klie, 1939 [Klie, 1939]

Strandesia mamarilorum Victor and Fernando, 1981 [Victor and Fernando, 1981]

= S. brteki Rybecký, 1988 [Rybecký, 1988]

Strandesia minuta Klie, 1936 [Klie, 1936]

= S. parva Hartmann, 1964 [Hartmann, 1964; Victor and Fernando, 1979a]

Strandesia obliqua (Brady, 1868) [Broodbakker, 1983; Meisch, 2000]

$=$ S. clorocelis Anichini, 1967 [Anichini, 1967]

$=$ S. sphaeroidea Broodbakker, 1983 [Broodbakker, 1983]

$=S$. mulargie Anichini, 1967 [Anichini, 1967]

=S. vavrai (G. W. Müller, 1898) [Bronstein, 1947]

Strandesia obtusata (Sars, 1901) [Sars, 1901; Roessler, 1990a]

$=S$. tolimensis Roessler, 1990 [Roessler, 1990a]

Strandesia psittacea (Sars, 1901) [Sars, 1901; Roessler, 1990b] =S. p. colombiensis Roessler, 1990 [Roessler, 1990b]

$=S$. trichosa Roessler, 1990 [Roessler, 1990b]

Strandesia purpurascens (Brady, 1886) [Victor and Fernando, 1979a, 1981]

= S. meghnae Harshey and Shrivastav, 1987 [Harshey and Shrivastav, 1987]

Strandesia rouxi Méhes, 1939 [Méhes, 1939]

=S. phoenix (De Deckker, 1981) [De Deckker, 1981]

Strandesia spinulosa Bronstein, 1958 [Akatova, 1958; Petkovski, 1964]

= S. tuberculata Hartmann, 1964 [Hartmann, 1964]

Strandesia ujijiensis Rome, 1962 [Rome, 1962]

$=S$. anterotundata Rome, 1977 [Rome and De Deckker, 1977]

Strandesia variegata (Sars, 1901) [Sars, 1901; Broodbakker, 1983]

= S. ovalis Tressler, 1949 [Tressler, 1949]

Strandesia victori Harshey and Spinivasan, 1987 [Harshey and Spinivasan, 1987]

$=S$. neelimae Harshey and Shrivastav, 1987 [Harshey and Shrivastav, 1987]

Strandesia vinciguerrae (Masi, 1905) [Masi, 1931]

= S. rotunda Hartmann, 1964 [Hartmann, 1964; Victor and Fernando, 1979a]
Strandesia vittata (Sars, 1903) [Victor and Fernando, 1981] $=S$. asymmetros Rome, 1962 [Rome, 1962]

= S. stocki Broodbakker, 1983 [Broodbakker, 1983]

Strandesia weberi Moniez, 1892 [Victor and Fernando, 1981]

= S. spinifera Hartmann, 1964 [Hartmann, 1964]

Strandesia wierzejskii (Grochmalicki, 1915) [Neale, 1977; Victor and Fernando, 1981]

= S. striatoreticulata Klie, 1932 [Klie, 1932]

Strandesia wolterecki Tressler, 1937 [Tressler, 1937; Victor and Fernando, 1981]

$=S$. chondropherusa Rome, 1965 [Rome, 1965]

$=S$. regularis Rome, 1962 [Rome, 1962]

\section{Key to species of Strandesia}

1. Swimming setae on A2 short (not reaching half L of penultimate segment)

- Swimming setae on A2 long (at least reaching tip of terminal claws)

2. Posterior and anterior margins of carapace in lateral view almost equally wide ............................. S. sudanica Sywula, 1970

- Posterior carapace margin narrower than anterior one .......... S. canadensis (Sars, 1926)

3. LV with one or two spine-like protuberances in the anterior part of carapace

- No spine-like protuberance present in the anterior part of carapace

4. Dorsal gibbosity on RV present

S. trispinosa (Pinto and Purper, 1965)

Dorsal gibbosity on RV absent

5. LV with a posterior protuberance

S. bicornuta Hartmann, 1964

- LV without a posterior protuberances S. weberi (Moniez, 1892)

6. RV with dorsal alae or spines ............................................ 7

- RV without dorsal alae or spines ........................................... 12

7. RV with two dorsal spines: one anterior, one posterior S. hartmanni (Victor, Paul and Fernando, 1980)

- RV with dorsal alae

8. Posterior margin of CR strongly serrated

- Posterior margin of CR finely serrated ……....................... 10

9. Inner margin of LV edged with denticles; dorsal alae frontally rounded, caudally pointed ............. S. bicuspis (Claus, 1892)

- Inner margin of LV without denticles; dorsal alae pointed at both ends ............................... S. mercatorum (Vávra, 1895)

10. RV antero-ventrally with a lip-like extension ................... 11

- RV antero-ventrally without a lip-like extension .................... S. pistrix Broodbakker, 1983

11. Carapace in lateral view elongated-ovate S. evae Gauthier, 1953

- Carapace in lateral view subelongated-ovate S. hancocki (Lowndes, 1931)

12. Valves with antero-lateral protuberances, sometimes also postero-laterally ....................... S. spinulosa Bronstein, 1958

- No such protuberances present ............................................. 13

13. Valves with two or more external spine-like setae on surface 
- No spine-like setae present on surface of the valves ........ 17

14. Each valve with only two postero-lateral spine-like setae ...

S. madhuriae Harshey and Shrivastav, 1987)

- Each valve with more than two spin-like setae ................. 15

15. Attachment of CR with Triebel-loop, and an additional small eye in the ventral branch S. perakensis Victor and Fernando, 1981

- CR with Triebel-loop only .. 16

16. Spines as long or shorter than normal surface setae S. dani George and Martens, 1993

- Spines much longer than normal surface setae S. trichurensis Victor and Fernando, 1980

17. RV on the antero-ventral margin with one more or less pronounced lip-like projection (parrot-beak like) well developed

- This projection absent 22

18. RV postero-distally with a small spine-like expansion, posterior and anterior margins otherwise equally wide ............. 19

- No spine-like expansion present ....... S. mutica (Sars, 1901)

19. Dorsal margin on both valves straight 20

- Dorsal margin on both valves arched 21

20. Anterior seta of CR exceeds anterior claw in length

S. ewaldi nom. nov.

- Anterior seta of CR shorter than anterior claw. S. iheringi (Sars, 1901) comb. nov.

21. Greatest $H$ of carapace situated around mid-length S. psittacea (Sars, 1901)

- Greatest H of carapace situated in front of mid-length S. inornata (Sars, 1901)

22. RV posteriorly very narrow, sometimes finishing in a spine-like

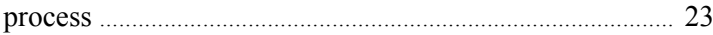

- RV posteriorly not so narrow, more evenly rounded ........ 31

23. LV with a small antero-dorsal protuberance

S. gopinathani George and Martens, 1993

- LV without such a protuberance ............................................. 24

24. Process on the caudal end of RV weakly developed ......... 25

- Process on the caudal end of RV well developed .............. 29

25. Anterior seta of CR longer than $1 / 2 \mathrm{~L}$ of the anterior claw 26

- Anterior seta of CR at the most reaches $1 / 2 \mathrm{~L}$ of the anterior claw

26. Dorsal margin of carapace highly arched in lateral view, greatest $\mathrm{H}$ in the first $1 / 3$ of $\mathrm{L}$

S. elliptica (Sars, 1901)

- Carapace not highly arched in lateral view

S. elegans Roessler, 1986

27. Carapace conspicuously high in lateral view S. obtusata (Sars, 1901)

- Carapace not conspicuously high in lateral view ............. 28 28. $\mathrm{L}$ ratio of anterior margin of $\mathrm{CR}$ and anterior claw less than $3: 1$....................................... S. maculatus (Müller, 1908)

- L ratio of anterior margin of CR and anterior claw more than $3: 1$............................................ S. cuneatus (Sars, 1895)

29. Greatest $\mathrm{H}$ of carapace equals $60 \%$ of $\mathrm{L}$

S. mucronata (Sars, 1901)

- Greatest H of carapace equals 50\% or less ...................... 30

30. Anterior seta of CR at the most reaching middle of the anterior claw S. episphaena (Müller, 1908)

- Anterior seta of CR exceeding middle of anterior Fu claw S. centrura Klie, 1940
31. Anterior and posterior margins of LV lined with tubercles (similar to those found in Heterocypris) .............................. 32

- This tubercles absent .............................................................. 38

32. Carapace subtriangular in lateral view, greatest $\mathrm{H}$ in front of

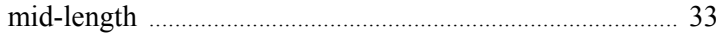

- Carapace different ..................................................................... 34

33. Anterior seta of CR equalling $1 / 2 \mathrm{~L}$ of anterior claw S. umbonata Victor and Fernando, 1981

- Anterior seta of CR much longer

S. kraepelini (Daday, 1910)

34. Dorsal margin of carapace rounded .................................... 35

- Dorsal margin of carapace straight ..................................... 37

35. Posterior claw of CR reaching about the middle of the anterior claw S. bornemiszai Klie, 1935

- Posterior claw of CR longer ............................................. 36

36. Ventral margin on RV convex in the mouth region (lip present) S. flavescens Klie, 1932

- Ventral margin not convex in the mouth region (no lip) ....... S. intrepida Furtos, 1936

37. RV with a well developed flange ... S. feuerborni Klie, 1932

- RV dorsally without a flange ................ S. carteri Klie, 1930

38. Claws of CR armed with distinct spines ........................... 39

- Claws of CR sometimes serrated but no spines present ... 45

39. Posterior margin of CR armed only with setulae

S. thermalis Rybecky, 1988

- Posterior margin of CR armed with group of spines ....... 40

40. Posterior margin of carapace distinctly narrower than the

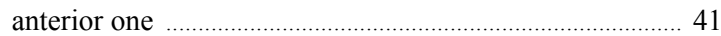

- Anterior and posterior margins almost equally wide ........ 42

41. Proximal shield of hemipenis distally rounded S. botosaneanui Broodbakker, 1983

- Proximal shield of hemipenis distally flat S. venezolana Broodbakker, 1983

42. RV with a lip-like flange on the anterior end S. odiosa (Moniez, 1892)

- RV without a lip-like flange on the anterior end ............... 43

43. En 2 segment on A1 four times longer than wide, medio-distal seta on the first segment on Mxl palp present

S. variegata (Sars, 1901)

- En2 segment on A1 less than four times longer than wide, mediodistal seta on the first segment on Mxl palp absent ........... 44

44. Distal claw on T2 longer than three distal segments combined ...................................... S. longula Broodbakker, 1983

- Distal claw on T2 shorter than three distal segments combined .............................. S. cavernicola Broodbakker, 1983

45. Anterior seta of $\mathrm{CR}$ not reaching $1 / 2 \mathrm{~L}$ of anterior Fu claw 46

- Anterior seta of CR much longer, at least reaching 2/3 of the anterior claw

46. In dorsal view, greatest $\mathrm{W}$ of carapace distinctly on first $1 / 3$ of L (tear shape) ........... S. mollis (Furtos, 1936) comb. nov.

- In dorsal view, greatest W of carapace around middle (egg shape) ............................................................................. 47

47. Carapace ornamented with rows of longitudinal ridges ........ S. amati (Martens, 1984)

- Carapace not ornamented

48

48. Anterior and posterior margins of carapace almost equally wide S. crassa Klie, 1939 
- Anterior margin distinctly wider than the posterior one ....... S. decorata (Sars, 1903)

49. Surface of carapace conspicuously well ornamented ....... 50

- Surface of carapace not well ornamented, sometimes covered with small and shallow pits, sometimes with tubercles (warts) 53

50. Surface of carapace ornamented with longitudinal ridges .... S. lineata Victor and Fernando, 1981

- Surface of carapace ornamented with a polygonal reticulation 51

51. Surface of carapace densely covered with tubercles S. wierzejskii (Grochmalicki, 1915)

- Surface tubercles sparse or absent 52

52 . Surface of carapace ornamented with blue spots, and elongated .................... S. victori Harshey and Spinivasan, 1987

- Carapace not ornamented with blue spots, and tumid ........... S. mamarilorum Victor and Fernando, 1981

53. In lateral view RV much higher than $\mathrm{LV}$, terminal segment of Mxl palp elongated (L:W ratio 3:1), setae $\mathrm{d} 1$ and $\mathrm{d} 2$ on $\mathrm{T} 2$ subequally long, CB1 seta transformed into sensory organ

S. kimberleyi $\mathrm{n}$. sp.

- In lateral view, asymmetry not pronounced, L:W ratio of terminal segment of Mxl palp less than 3:1, d1 seta much longer than $\mathrm{d} 2, \mathrm{CB} 1$ seta completely absent ....................... 54

$54 . \mathrm{H}: \mathrm{L}$ ratio of carapace equal or less than $50 \%$ of $\mathrm{L}$.......... 55

- Carapace higher, H:L ratio more than $55 \%$ of L ............... 59

55. Valves with a pigmentary pattern ………............................ 56

- Valves without a pigmentary pattern …………..................... 57

56. Valves with an expansion in the mouth region (lip)

S. complexa Victor and Fernando, 1981

- Valves without an expansion in the mouth region (lip) .........

S. sexpunctata Klie, 1932

57. Anterior margin of CR concave, posterior margin of carapace forms a slight angle with dorsal margin

S. saetosa Hartmann, 1964

- Anterior margin of CR straight, posterior margin of carapace evenly rounded

58. A small expansion in the mouth region (lip) present S. calapanensis Tressler, 1937

- No expansion in the mouth region (lip) S. purpurascens (Brady, 1886)

59. Posterior margin of $\mathrm{CR}$ armed with spines ........................ 60

- Posterior margin of CR armed with setulae ....................... 62

60. Valves with an expansion in the mouth region (lip)

S. labiata Hartmann, 1964

- Valves without an expansion in the mouth region (lip) .... 61

61. Valve surface with a pigmentary pattern

S. wolterecki Tressler, 1937

- Valve surface without a pigmentary pattern S. unicolor Klie, 1944

62. Valve surface densely covered with tubercles S. freyi Victor and Fernando, 1981

- Valve surface not covered with tubercles at all ................. 63 63. Anterior inner margin straight not following the outer one .. S. ujijiensis Rome, 1962

- Anterior inner margin following the outer one ................. 64 64. LV posteriorly with a flange ... S. vinciguerrae (Masi, 1905)

- LV without a flange 65
65. Valves with an expansion in the mouth region (lip) S. vittata (Sars, 1903)

- Valves without an expansion in the mouth region (lip) .... 66 66. Anterior margin of carapace wider than the posterior one ... S. obliqua (Brady, 1868)

- Anterior and posterior margins of carapace equally wide... 67

67. Greatest $\mathrm{H}$ situated of carapace in front of the middle, dorsal margin highly arched on that point ...... S. minuta Klie, 1936

- Greatest H situated in the middle of carapace, dorsal margin evenly arched S. rouxi Méhes, 1939

\section{Acknowledgement}

I wish to thank Dr G.L. Pesce (University l'Aquila, Italy) and Dr Y. Ranga-Reddy (Nagarjuna University, India) for sending me ostracod material. Dr Claude Meisch (Natural History Museum, Luxembourg), and another anonymous referee suggested many very important improvements to the manuscript. I am also grateful to Ms W. Crawford (Library of the Western Australian Museum) for providing me with so many references.

\section{References}

Akatova NA. 1958. Strandesia spinulosa Bronstein (in litt.) sp. n. (Ostracoda). Dokl. Akad. Nauk tadzh. SSR 1: 37-39.

Anichini G. 1967. Gli Ostracodi della Sadegna. Rend. Semin. Fac. Sci. Univ. Cagliari 37: 1-42.

Brady GS. 1868. A monograph of the Recent British Ostracoda. Trans. Linn. Soc. London 26: 353-495.

Brady GS. 1886. Notes on Entomostraca collected by Mr A. Haly in Ceylon. J. Linn. Soc. London, Zool. 19: 293-317.

Bronstein ZS. 1947. Rakoobraznye 2, Ostracoda presnykh vod. In: Shtakelyberg AA, ed. Fauna SSSR 31. Zool. Inst. Akad. Nauk SSSR, Moskva, 1-339.

Broodbakker NW. 1983. The genus Strandesia and other Cypricercini (Crustacea, Ostracoda) in the West Indies. Part II. Taxonomy. Bijdr. Dierk. 53: 327-368.

Broodbakker NW. 1984. The genus Tanycypris (Crustacea, Ostracoda) in the West Indies. Bijdr. Dierk. 54: 15-24.

Broodbakker NW, Danielopol DL. 1982. The chaetotaxy of Cypridacea (Crustacea, Ostracoda) limbs: proposal for a descriptive model. Bijdr. Dierk. 52: 103-120.

Claus C. 1892. Beiträge zur Kenntnis des Süsswasser-Ostracoden. I. Über den Körper- und Gliedmassenbau der Cypriden nebst Bemerkungen über einzelne innere Organe derselben. Arb. Zool. Inst. Univ. Wien Zool. Stat. Triest 10: 147-216.

Deckker P de. 1981. Taxonomy and ecological notes of some ostracods from Australian inland waters. Trans. R. Soc. S. A. 105: $91-138$

Fox, MH. 1967. More new and interesting Cyprids (Cristacea, Ostracoda) in Britain. J. Nat. Hist. 1: 549-559. 
George S, Martens K. 1993. Two new species of freshwater Ostracoda of the genus Strandesia Stuhlmann, 1888 from Kerala, India. J. Nat. Hist. 27: 255-265.

Harshey DK, Shrivastav AK. 1987. Three new species of Strandesia Vávra, 1895 (Crustacea, Ostracoda) from India. $J$. Curr. Biosci. 4: 43-48.

Harshey DK, Shrivastav AK. 1987. A new species of Strandesia Vavra, 1895 (Crustacea, Ostracoda) from India. Biovigyanam 13: $104-106$.

Hartmann G. 1964. Asiatische Ostracoden. Systematische und zoogeographische Untersuchungen. Int. Rev. Ges. Hydrobiol. Syst. Beih. 3: 7-155.

Hartmann G, Puri HS. 1974. Summary of Neontological and Paleontological classification of Ostracoda. Mitt. Hamb. Zool. Mus. Inst. 70: 7-73.

International Commission on Zoological Nomenclature. 1999. International Code of Zoological Nomenclature, fourth edition. The International Trust for Zoological Nomenclature, London, pp. 1-306.

Karanovic I. 2005. Comparative morphology of the Candoninae antennula, with remarks on the ancestral state in ostracods (Crustacea, Ostracoda) and proposed new terminology. Spixiana 28: 141-160.

Kempf, EK. 1980. Index and bibliography of non-marine ostracoda, 1. Index A. Geol. Inst. Univ. Koeln Sonderv. 35: 1-188.

Kempf, EK. 1997. Index and bibliography of non-marine ostracoda, 6. Index A, supplement 1. Geol. Inst. Univ. Koeln Sonderv. 109: 1-142.

Klie W. 1932. Die Ostracoden der Deutschen Limnologischen Sunda Expedition. Arch. Hydrobiol. 11: 447-502.

Klie W. 1935. Voyage de Ch. Alluaud et P.A. Chappuis en Afrique Occidentale Française (1930-1931). VIII. Ostracoda aus dem tropischen Westafrika. Arch. Hydrobiol. 28: 35-68.

Klie W. 1936. Ostracoden aus Kamerun. Rev. Zool. Bot. Afr. 28: 287-307.

Klie W. 1939. Ostracoden aus dem Kenia-Gebiet, vornehmlich von dessen Hochgebirgen. Int. Rev. ges. Hydrobiol. Hydrogr. 39: $99-161$.

Klie W. 1940. Süsswasserostracoden aus Nordostbrasilien. $V$. Zool. Anz. 129: 201-206.

Maddocks, RF. 2000. The antennula in podocopid Ostracoda: chaetotaxy, ontogeny, and morphometries. Micropaleontology 2: 1-37.

Martens K. 1987. Homology and functional morphology of the sexual dimorphism in the antenna of Sclerocypris Sars, 1924 (Crustacea, Ostracoda, Megalocypridinae). Bijdr. Dierk. 57: 183-190.

Martens K. 1989. Redescription and taxonomical position of Strandesia sudanica Sywula, 1970 (Crustacea, Ostracoda). Bull. Soc. Nat. Luxemb. 89: 211-220.

Martens K. 1994. Towards a revision of the Cypricercinae (Crustacea, Ostracoda): on the validity of the genera Neocypris Sars, 1901 and Bradleycypris McKenzie, 1982. Bull. Inst. R. Sci. Natur. Belg., Bio. 64: 231-233.

Martens K. 1998. General morphology of non-marine Ostracods. In: Martens K, ed. Sex and Parthenogenesis: evolutionary ecology of reproductive modes in non-marine ostracods. Backhuys Publishers, Leiden, The Netherlands, 57-75.
Masi L. 1931. Spedizione scientifica all'Oasi di Cufra. Ann. Mus. Civ. Stor. Nat. Giacomo Doria 55: 310-328.

McKenzie, KG. 1965. Freshwater ostracoda from North-Western Australia. Aust. J. Mar. Freshwat. Res. 17: 259-179.

McKenzie, KG. 1971. Species list of South African freshwater ostracoda with an appendix listing Museum collections and some further determinations. Ann. S. A. Mus. 57: 157-213.

McKenzie, KG. 1982. Homeomorphy: Persistant joker in the taxonomic pack, with the description of Bradleycypris gen. nov. In: Bate RH, Robinson E, Sheppard LM, eds. Fossil and Recent Ostracods. Chichester, 407-438.

Meisch C. 1979. Cypricercus alacer n. sp. (Crustacea, Ostracoda) en provenance du Grand-Duché de Luxembourg. Arch. Inst. grand-ducal Lux., sec. sci. nat., phys. mathém. 38: 191-196.

Meisch C. 1996. Contribution to the taxonomy of Pseudocandona and four related genera, with the description of Schellencandona nov. gen., a list of the Candoninae genera, and the key to the European genera of the subfamily (Crustacea, Ostracoda). Bull. Soc. Nat. Luxemb. 97: 211-237.

Meisch C. 2000. Freshwater Ostracoda of Western and Central Europe. In: Schwoerbel J, Zwick P, eds. Süsswasserfauna von Mitteleuropa 8/3. Spektrum Akademisher Verlag, Berlin, 1522.

Méhes G. 1939. Ostracodes de la Nouvelle-Calédonie. Rev. Suis. Zool. 46: 549-566.

Müller GW. 1912. Crustacea: Ostracoda. Das Tierreich 31: $1-434$.

Neale JW. 1977. Ostracodes from the rice-fields of Sri Lanka (Ceylon). In: Löffler H, Danielopol DL, eds. Aspects of ecology and zoogegraphy of recent and fossil Ostracodes. Dr N. Junk publishers. The Hague, 271-283.

Petkovski TK. 1964. Bemerkenswerte Entomostraken aus Jugoslavien. Acta Mus. Maced. Sci. Nat. 9: 147-181.

Roessler EW. 1986. Estudios taxonomicos, ontogeneticos, ecologicos y etologicos sobre los ostracodos de agua dulce en Colombia - VI. Estudio taxonomico del genero Strandesia Stuhlmann 1888 (Ostracoda, Podocopida, Cyprididae). Caldasia 15: 71-75.

Roessler EW. 1990a. Estudios taxonomicos, ontogeneticos, ecologicos y etologicos sobre los ostracodos de agua dulce en Colombia (Ostracoda, Podocopida, Cyprididae). VI Estudio taxonomico del genero Strandesia Stuhlmann 1888 - Parte III. El grupo 'Strandesia elliptica (Sars, 1901)'. Rev. Acad. Colomb. Cienc. 17: 795-804.

Roessler EW. 1990b. Estudios sobre los ostracodos de agua dulce en Colombia. VI-IV. Estudio taxonomico del grupo Strandesia psittacea psittacea. Caldasia 16: 215-230.

Rome DR. 1962. Ostracodes. Expl. Hydrobiol. Lac Tanganika (1946-1947). Res. Sci. 3: 1-305.

Rome DR. 1965. Ostracodes. Expl. Parc Nat. Upemba. Mission G.F. de Witte 69: 3-71.

Rome DR, Deckker P de. 1977. Ostracodes du Lac Kivu. Mém. Inst. Géol. Univ. Louvain 29: 241-268.

Rybecký M. 1988. Zwei neue arten der Ostracodengattung Strandesia Vávra, 1895 aus thermalgewässern der Slowakei. Annot. Zool. Botan. 187: 1-8.

Sars GO. 1895. On some South-African Entomostraca raised from dried mud. Vidensk.-Selsk. Skr. I. Mathem.-naturv. Kl. 8: $1-56$. 
Sars GO. 1901. Contributions to the knowledge of the Fresh-water Entomostraca of South America as shown by artificial hatching from dried material. Arch. Mathem. Naturvid. 24: 3-52.

Sars GO. 1924. The fresh-water Entomostraca of the Cape Province (Union of South Africa. Part II: Ostracoda. Ann. S. A. Mus. 20: 105-193.

Sars GO. 1925. An account of the Crustacea of Norway with short descriptions and figures of all the species. 9. Ostracoda. Parts V-X: 73-176.

Stuhlmann F. 1888. Vorläufiger Bericht über eine mit Unterstützung der Königlichen Akademie der Wissenschaften unternommene Reise nach Ost-Africa zur Untersuchung der Süsswasserfauna. Sitz. Königl. Preuss. Akad. Wissensch. Berlin 2: 1255-1269.

Tressler WL. 1937. Ostracoda. Int. Rev. ges. Hydrobiol. Hydrogr. 34: 187-207.

Tressler WL. 1949. Fresh-water Ostracoda from Brazil. Proc. U. S. Nat. Mus. 100: 61-83.

Vávra V. 1895. Süsswasser-Ostracoden Zanzibar's. Hamb. Wiss. Anst. 12: 2-23.
Victor R, Fernando CH. 1979a. The freshwater ostracods (Crustacea: Ostracoda) of India. Rec. Zool. Surv. Ind. 74: 147-242.

Victor R, Fernando CH. 1979b. On some freshwater ostracod type specimens from Indonesia. Can. J. Zool. 57: 6-12.

Victor R, Fernando CH. 1981. Freshwater ostracods (Crustacea: Ostracoda) of the genus Strandesia Vavra, 1895 from Malaysia, Indonesia and the Philippines. Arch. Hydrobiol. Suppl. 58: 469-522.

Vigna Taglianti A, Cottarelli V, Argano A. 1969. Messa a punto di metodiche per la racolta della fauna interstiziale e freatica. Arch. Bot. Biogeogr. It. 14: 375-380.

Wouters K. 1999. Two new species of the genus Phlyctenophora Brady, 1880 (Crustacea, Ostracoda) from the Indo-Pacific realm. Bull. Inst. R. Sci. Natur. Belg., Biol. 69: 83-92.

Received: 7 February 2005

Accepted: 6 August 2005 
